\title{
KAJIAN PERBANDINGAN DALAM PEMBAGIAN WARIS BERDASARKAN PADA HUKUM ISLAM DAN HUKUM ADAT
}

\author{
Anwar Hidayat \\ Email: Anwar.hidayat@ubpkarawang.ac.id \\ M. Gary Gagarin Akbar \\ Email: gary.akbar@ubpkarawang.ac.id \\ Deny Guntara \\ Email: deny.guntara@ubpkarawang.ac.id \\ Universitas Buana Perjuangan Karawang
}

\begin{abstract}
Abstrak
Pemberlakuan aturan mengenai kewarisan di Indonesia selama ini terjadi perdebatan antara para ahli hukum tentang status hukum Islam dan hukum adat.Berkaitan dengan permasalahan dalam hukum waris pada hukum Islam dan hukum Adat, maka perlu adanya kesesuaian bagi masyarakat yang akan mempergunakan masing-masing hukum tersebut dalam menyelesaian warisannya kepada sang ahli waris yang berhak. Ketentuan hukum Islam di Indonesia belum merupakan undang-undang (kodifikasi) haruslah sistematis dan prosedural, harus jelas siapa subyek dan obyeknya dan diundangkan oleh lembaga yang berwenang dalam negara. Rumusan masalah dalam penelitian ini adalah bagaimana perbandingan dalam pembagian waris berdasarkan pada hukum islam dan hukum adat. Metode penelitian ini menggunakan metode kualitatif dengan metode pendekatan yuridis empiris. Hasil penelitian yaitu Hukum waris Islam telah menempatkan atauran kewarisan dan hukum mengenai harta benda dengan sebaik-baiknya dan seadil-adilnya. Islam menetapkan hak milik seseorang atas harta, baik bagi laki-laki maupun perempuan seperti perpindahan hak milik dan perempuan pada waktu masih hidup atau perpindahan harta kepada ahli warisnya setelah ia meninggal dunia. Hukum waris adat berpangkal dari bentuk masyarakat dan sifat kekeluargaan yang terdapat di Indonesia menurut sistem keturunan, dan setiap sistem keturunan yang ada mempunyai kekhususan dalam hukum waris yang satu dengan yang lain berbeda-beda.
\end{abstract}

Kata Kunci:Waris, Hukum Islam, Hukum Adat

\begin{abstract}
The enactment of the rules regarding inheritance in Indonesia has been a debate between legal experts about the status of Islamic law and customary law. In connection with problems in inheritance law in Islamic law and Customary law, it is necessary for the community to use each of these laws in complete the inheritance to the rightful heirs. The provisions of Islamic law in Indonesia are not yet laws (codification) must be systematic and procedural, it must be clear who the subject and object are and are promulgated by the authorized institutions in the country. The formulation of the problem in this study is how comparisons in inheritance distribution are based on Islamic law and customary law. This research method uses qualitative methods with an empirical juridical approach method. The results of the research, namely Islamic inheritance law has placed the inheritance and law regarding property as well as possible and as fair as fair. Islam establishes someone's property rights, both for men and women, such as the transfer of property rights and women while still alive or the transfer of property to his heirs after he dies. The customary inheritance law stems from the form of the community and the family character found in Indonesia according to the hereditary system, and each of the offspring systems that have specific inheritance laws is different from one another.
\end{abstract}

Keyword: Inheritance, Islamic Law, Customary Law 
KAJIAN PERBANDINGAN DALAM PEMBAGIAN WARIS BERDASARKAN PADA HUKUM

ISLAM DAN HUKUM ADAT: Anwar Hidayat, M. Gary Gagarin. A, Deny Guntara

\section{PENDAHULUAN}

Hukum yang berkembang pada masyarakat merupakan suatu sistem penting dalam mengatur kehidupan yang berhubungan dengan suatu tatanan kehidupan seperti tatanan sosial masyarakat yang bertujuan untuk mendisiplinkan peristiwa yang kacau. Oleh karena itu, adanya hukum menjadikan sebuah sistem pengatur dalam segala aspek kehidupan masyarakat. Hukum merupakan hasil dari pengejawantahan dari nilai dan norma yang berkembang di masyarakat.

Sehingga tujuan hukum sebagai sarana untuk patokan perilaku manusia dalam menentukan setiap perbuatan yang dilakukan akan memberikan dampak dari peristiwa hukum tersebut.

Hukum dan manusia mempunyai hubungan yang khas dan tidak dapat dipisahkan. Hukum ada untuk memberikan aturan bagi manusia yang menerapkan hukukm tersebut, tanpa adanya manusia maka hukum tersebut tidak ada fungsinya bagi kehidupan. Hukum Islam dan paranata sosial sebagai unsur normatif dalam penataan kehidupan manusia berpangkal dari keyakinan dan penerimaan terhadap sumber ajaran Islam seperti yang termaktub dalam Al-quran dan hadis. Kedua sumber ini lalu dijadikan rujukan dalam menata hubungan antara manusia dengan makhluk lainnya. Hukum dideduksi secara preskriptif dari sumbernya (mashdir al-ahkam), sedangkan pranata diinduksi dari prepenataan untuk memenuhi kebutuhan hidup manusia yang spesifik. ${ }^{1}$

Ketentuan hukum yang berlaku akan mempunyai muatan ide yang terkandung di dalamnya, dengan mempertimbangkan dengan semua kepentingan yang ada di tengah-tengah komunitas masyarakat. Hukum yang berkembang di suatu masyarakat mempunyai tujuan yang akan diwujudkan. Produk hukum mempunyai tujuan yang hanya dapa diwujudkan melalui pelaksanaan, penerapan dan penegakan hukum (law enforcement). Adapun tujuan hukum yang dimaksud berorientasi pada persamaan hak, kewajiban dan kedudukan di depan

\footnotetext{
${ }^{1}$ Amin Abdullah, Studi Agama: Normatifitas atau Historisitas?, Pustaka Pelajar, Yogyakarta, 1996, hal 65
} 
KAJIAN PERBANDINGAN DALAM PEMBAGIAN WARIS BERDASARKAN PADA HUKUM

ISLAM DAN HUKUM ADAT: Anwar Hidayat, M. Gary Gagarin. A, Deny Guntara

hukum (equality before the law), serta hukum tidak diskriminatif.

Bangsa Indonesia mempunyai ketentuan hukum yang bentuknya tertulis dalam peraturan perundangundangan serta hukum yang oleh masyarakat setempat menyakini sebagai aturan yang dijadikan sebagai pedoman hidupnya yakni hukum adat. Berkaitan dengan hukum waris bahwa aturan hukum secara nasional belum terbentuk, oleh karenanya ketentuan yang masih berlaku di Indonesia mengenai hukum waris terdapat pada hukum waris yang berdasarkan hukum Islam, hukum Adat dan hukum Perdata Eropa (BW). Hal tersebut merupakan akibat warisan hukum yang dibuat oleh pemerintah kolonial Belanda untuk Hindia Belanda ketika itu. Hukum waris ialah hukum yang mengatur mengenai apa yang harus terjadi dengan harta kekayaan seseorang yang telah meninggal dunia, dengan perkataan lain mengatur peralihan garta kekayaan yang ditinggalkan oleh seseorang yang meninggal dunia beserta akibat-akibatnya bagi ahli waris. ${ }^{2}$

Permasalahan mengenai waris Islam merupakan sebagian dari masalah ang

\footnotetext{
${ }^{2}$ Agil Jaelani, Andri Milka, dan Muhammad Iqbal Kraus, Perbandingan Antara Hukum Waris
}

serius tentang hukum Islam yang harus diberikan penyelesaian dan solusi. Adanya kerancauan di dalam fiqh waris sulit dipahami dan telah menjadi kegelisahan umat Islam untuk berada dalam satu pandangan Islam dan menganut hukum waris yang seragam. Berkaitan dengan permasalahan dalam hukum waris pada hukum Islam dan hukum Adat, maka perlu adanya kesesuaian bagi masyarakat yang akan mempergunakan masing-masing hukum tersebut dalam menyelesaian warisannya kepada sang ahli waris yang berhak. Ketentuan hukum Islam di Indonesia belum merupakan undang-undang (kodifikasi) haruslah sistematis dan prosedural, harus jelas siapa subyek dan obyeknya dan diundangkan oleh lembaga yang berwenang dalam negara.

Masyarakat Indonesia merupakan penduduk yang mayoritas bergama Islam, namun masih banyak masyarakat tersebut belum memahami dan atau bersedia mengamalkan hukum Islam secara utuh. Dengan kesadaran masyarakat yang beragama Islam cukup tinggi maka dengan sendirinya mereka mendukung pelaksanaan hukum Islam

Perdata Barat dengan Hukum Waris Islam, Artikel Hukum, 2016, hal 1 
KAJIAN PERBANDINGAN DALAM PEMBAGIAN WARIS BERDASARKAN PADA HUKUM

ISLAM DAN HUKUM ADAT: Anwar Hidayat, M. Gary Gagarin. A, Deny Guntara

(termasuk hukum waris). Sehingga dengan adanya kesadaran segala macam permasalahan mengenai hukum Islam akan terselesaikan dengan baik. Hukum Islam telah meletakkan aturan mengenai kewarisan dan hukum mengenai harta benda dengan sebaik-baiknya dan seadiladilnya. Islam menetapkan hak milik seseorang atas harta, baik laki-laki maupun perempuan seperti perpindahan harta kepada ahli warisnya setelah ia meninggal dunia. Dalam hukum Islam tidak mendiskriminasikan antara hak anak kecil dan orang dewasa. Selain itu, hukum Islam wajib diyakini sebagai bagian dari hukum Islam yang pelaksanaannya tidak dapat dipisahkan dari iman dan aqidah.

Pemberlakuan aturan mengenai kewarisan di Indonesia selama ini terjadi perdebatan antara para ahli hukum tentang status hukum Islam dan hukum adat. Pada akhir abad sembilan belas berkembang paham bahwa orang Islam di Indonesia telah menerima dan memberlakukan hukum Islam secara keseluruhan. Teori reception in complexu, pendapat ini dipelopori oleh Salomo Keyzer (1823-1868) dan L.W.C.
Van den Berg (1845-1927). Pendapat di atas kemudian ditantang oleh C. Snouck Hurgronje (1857-1936), Cornelis Van Volleenhouven dan Bertrand Ter Har. Menurut mereka yang berlaku bagi orang Islam Indonesia bukan hukum Islam, tetapi hukum adapt, namun sesungguhnya telah diterima sebagai hukum Islam. Unsur hukum Islam yang demikian sudah diakui sebagai unsurunsur hukum adapt itu sendiri. ${ }^{3}$

Ketentuan mengenai hukum adat, pada dasarnya setiap regulasi (hukum dilahirkan dan bersumber dari hukum adat. Alasannya ialah hukum adat merupakan hukum yang hidup dalam masyarakat. Akan tetapi meskipun hukum adat menjadi sumber dalam pembuatan peraturan perundangundangan, hanya sebagian diantaranya yang bisa diakomodir oleh pemerintah untuk dijadikan ketentuan hukum positif. Mengenai ketentuan kewarisan dalam hukum adat yang ada di Indonesia sangatlah bervariasi. Hukum waris adat ditentukan adanya faktor sistem keturunan yakni sistem kemasyarakatan kebapakan (patrilineal); sistem kemasyarakatan keibuan (matrilineal);

\footnotetext{
${ }^{3}$ Muhammad Daud Ali, Asas-asas Hukum Islam, Rajawali Pers, Jakarta, 2000, hal 16-17
} 
KAJIAN PERBANDINGAN DALAM PEMBAGIAN WARIS BERDASARKAN PADA HUKUM

ISLAM DAN HUKUM ADAT: Anwar Hidayat, M. Gary Gagarin. A, Deny Guntara

dan sistem kebapak-ibuan

hukum kewarisan Islam tidaklah

(parental/bilateral).

Sebagai contoh bahwa pembagian waris berdasarkan sistem parental/bilateral yaitu pembagian warisan yang ditarik menurut garis orang tua (bapak-ibu) dimana kedudukan pria dan wanita tidak ada perbedaan dalam hal mendapatkan harta pewarisan. Sedangkan dalam hukum kewarisan Islam, sudah ada aturan dan pembagian khusus terhadap harta peninggalan (tirkah) dari pewaris kepada ahli warisnya. Kemudian yang menjadi patokan adalah pembagian antara lakilaki dan perempuan adalah dua banding satu (2:1). Oleh karena itu, sangat berbeda bila dibandingkan dengan ketentuan waris yang diatur dalam hukum adat.

Persoalan yang demikian itu menjadi sorotan ketika masyarakat Indonesia merupakan mayoritas beragama Islam sehingga akan menegakan aturan yang diatur oleh hukum Islam. Akan tetapi, masyarakat lebih cenderung menggunakan hukum adat sebagai pedoman atau ketentuan yang digunakan dalam hal pembagian kewarisan yang menjadi persoalan dalam kehidupannya. Keberadaan berlaku, bagi masyarakat lebih memakai dna menggunakan hukum kewarisan adatnya dibanding hukum kewarisan Islam, bahkan lebih sering digunakan adanya upaya musyawarah secara kekeluargaan. Karena kebiasaankebiasaan seperti ini sering dilakukan, sehingga menjadi yurisprudensi dan ketetapan hukum setempat kemudian menjadi adar atau tradisi yang berlaku.

Bangsa Indonesia merupakan masyarakat yang penduduknya mayoritas beragama Islam, sehingga masyarakat Indonesia memerlukan produk hukum waris yang sesuai dengan ketentuan bagi masyarakat yang beragama Islam yang berlaku secara nasional. Seperti halnya mengenai hukum perkawinan yang diatur di dalam Undang-Undang Nomor 1 Tahun 1974 tentang Perkawinan, merupakan produk hukum yang berlaku secara nasional bagi masyarakat Indonesia yang beragama Islam, dimana dalam perkawinan harus didasarkan pada aturan tersebut. Dengan demikian, kaitannya dengan waris perlu di dalam menyusun ketentuan mengenai hukum waris nasional mampu kiranya ketentuan-ketentuan pokok hukum waris Islam dimasukkan ke dalamnya, namun 
KAJIAN PERBANDINGAN DALAM PEMBAGIAN WARIS BERDASARKAN PADA HUKUM ISLAM DAN HUKUM ADAT: Anwar Hidayat, M. Gary Gagarin. A, Deny Guntara

tetap memperhatikan falsafah Pancasila serta pola budaya atau adat yang hidup di masyarakat Indonesia itu sendiri yang sangat beraneka ragam.

\section{PERMASALAHAN}

Berdasarkan hal-hal yang telah diungkapkan dalam latar belakang, maka dibuat rumusan masalah sebagai berikut

1. Bagaimana perbandingan mengenai Hukum Waris dalam ketentuan hukum Islam (Kompilasi Hukum Islam) dan hukum Adat di Indonesia?

2. Bagaimanakah kajian filosofis mengenai Hukum Waris berlandaskan pada nilai-nilai Pancasila Bangsa Indonesia?

\section{HASIL DAN PEMBAHASAN}

1. Perbandingan mengenai Hukum Waris dalam ketentuan hukum Islam (Kompilasi Hukum Islam) dan hukum Adat di Indonesia

a. Hukum Kewarisan Berdasarkan Hukum Islam (Kompilasi Hukum Islam)

\footnotetext{
4 Muhammad Ali Ash-Shabuni, Pembagian Waris Menurut Islam, (penerjemah : A.M Basamalah), Gema Insani Press, 1995, diakses dari www.kewarisan.com
}

Pandangan Hukum Waris berdasarkan pada Hukum Islam, bahwa waris berasal dari bahasa Arab yaitu $\mathrm{Al}$ miirats, bentuk masdar dari kata waritsyaritsu-irtsan-miiraatsan. Dimana dari pengertian-pengertian tersebut mempunyai makna berpindahannya sesuatu dari seseorang kepada orang lain, atau dari suatu kaum kepada kaum lain. Sedangkan makna al-miirats menurut istilah adalah hak kepemilikan dari orang yang meninggal kepada ahli warisnya yang masih hidup, baik yang ditinggalkan itu berupa harta (uang), tanah, atau apa saja yang berupa hak milik legal secara syar'i. ${ }^{4}$

Menurut Idris Djakfar dan Taufik Yahya, bahwa hukum kewarisan ialah seperangkat ketentuan yang mengatur ara-cara peralihan hak dari seseorang yang telah meninggal dunia kepada orang yang masih hidup yang ketentuanketentuan tersebut berdasarkan pada wahyu Illahi yang terdapat dalam Alquran dan penjelasannya yang diberikan oleh Nabi Muhammad SAW, dalam istilah Arab disebut sebagai Faraidl. ${ }^{5}$ Ketentuan di dalam Pasal 171

\footnotetext{
5 Idris Djakfar dan Taufik Yahya, Kompilasi Hukum Kewarisan Islam, PT. Dunia Pustaka Jaya, Jakarta, 1995, hal 3-4
} 
KAJIAN PERBANDINGAN DALAM PEMBAGIAN WARIS BERDASARKAN PADA HUKUM

ISLAM DAN HUKUM ADAT: Anwar Hidayat, M. Gary Gagarin. A, Deny Guntara

huruf (a) Kompilasi Hukum Islam telah

mendefinisikan bahwa hukum kewarisan

adalah hukum yang mengatur tentang

pemindahan hak pemilikan harta

peninggalan (tirkah) pewaris.

Pewarisan menurut sebagian besar ahli hukum islam adalah semua harta benda yang ditinggalkan oleh seorang yang meninggal dunia baik berupa benda bergerak maupun benda tetap, termasuk berang/uang pinjaman dan juga barang yang ada sangkut pautnya dengan hak orang lain, misalnya barang yang digadaikan sebagai jaminan atas hutangnya ketika pewaris masih hidup. ${ }^{6}$ Ketentuan Allah SWT yang memerintahkan agar setiap orang yang beriman mengikuti ketentuan-ketentuan Allah SWT menyangkut hukum kewarisan sebagaimana yang termaktub dalam kitab suci Al-quran dan menjanjikan siksa neraka bagi orang yang melanggar peraturan ini. ${ }^{7}$

\footnotetext{
${ }^{6}$ Masjfuk Zuhdi, Study Islam, Jilid III, Raja Grafindo, Jakarta, 1993, hal 57.

7 Dalam Q.S AN-Nisa ayat 13 dan 14, Allah SWT berfirman : Terjemahannya "Hukumhukum tersebut adalah ketentuan-ketentuan dari Allah, barang siapa yang taat pada (hukum-hukum) Allah dan RasulNya, niscaya Allah akan memasukannya ke dalam surga yang mengalir di dalamnya sungai-sungai, sedang mereka (akan) kekal di dalamnya. Dan yang demikian tersebut merupakan
}

Persoalan hukum kewarisan Islam merupakan sebagian dari sekian masalah serius tentang hukum Islam yang harus segera diselesaikan. Di bawah kerancauannya fiqih waris sulit dipahami dan telah menjadi kegelisahan umat Islam untuk berada dalam satu pandangan Islam dan menganut hukum waris yang seragam. Sebenarnya di Indonesia sudah terlahir produk hukum yang berkaitan dengan permasalahan hukum dengan munculnya Kompilasi Hukum Islam (KHI) sebagai hukum tertulis yang diberlakukan sebagai pedoman khusus bagi umat Islam dalam menyelesaikan segala permasalahann hukum termasuk mengenai pembaharuan hukum kewarisan Islam Indonesia. $^{8}$

Hukum waris yang berlaku sesuai dengan hukum islam tentu belandasakan pada Al-quran dan hadist-hadist Rasulullah SAW, sebagaimana telah diuraikan sebelumnya, maka terdapat

kemenangan yang besar. Dan barang siapa yang mendurhakai Allah dan RasulNya, serta melanggar ketentuan (hukum-hukum) Allah dan RasulNya, Niscaya Allah akan memasukannya ke dalam api neraka, sedangkan mereka akan kekal di dalamnya, dan baginya siksa yang amat menghinakan

8 Ali Raja, Pembaharuan Hukum Kewarisan Islam di Indonesia (Stdui Komparatif Pemikiran Hazairin dan Munawir Sjadzali), UIN Sunan Kalijaga Yogyakarta. 
asas yang harus diperhatikan dalam pelaksanaan hukum waris tersebut. Menurut Muhammad Daud Ali ${ }^{9}$ dalam kewarisan hukum Islam terdapat 5 (lima) asas antara lain sebagai berikut :

a) Asas Ijbari yaitu peralihan harta seseorang yang te;lah meninggal dunia kepada yang masih hidup berlaku dengan sendirinya yang dalam pengertian hukum Islam berlangsung secara ijbari. Hal ini mengandung pengertian bahwa peralihan harta warisan seorang pewaris yang meninggal dunia kepada ahli warisnya berlaku dengan sendirinya sesuai dengan ketetapan Allah swt, tanpa digantungkan kepada kehendak pewaris atau ahli waris dengan bagian yang telah ditetapkan.

b) Asas Bilateral, yaitu seseorang menerima warisan dari kedua belah pihak kerabat, yaitu baik kerabat garis keturunan lakilaki maupun dari pihak kerabat garis keturunan perempuan.
Asas tersebut mengandung pengertian bahwa seseorang yang menjadi ahli waris dari kedua garis kerabat, yakni dari pihak ayah dan pihak ibu. Asas ini dapat dilihat dalam surat anNisa ayat 7 yang maksudnya bahwa laki-laki ada bagian dari peninggalan ibu bapaknya dan karibnya.

c) Asas Individual yaitu harta peninggalan yang ditinggalkan oleh yang meninggal dunia, dibagi secara individual atau secara pribadi langsung kepada masing-masing individu.

d) Asas Keadilan Berimbang yaitu baik laki-laki maupun perempuan sama-sama berhak tampil sebagai ahli waris, mewarisi harta peninggalan yang ditinggalkan oleh pewaris. Asas tersebut mengandung pengertian bahwa harus senantiasa terdapat keseimbangan antara hak dan kewajiban, antar hak yang diperoleh seseorang dengan kewajiban yang harus

\footnotetext{
${ }^{9}$ Muhammad Daud Ali, 2000, hal 281-287
} 
KAJIAN PERBANDINGAN DALAM PEMBAGIAN WARIS BERDASARKAN PADA HUKUM

ISLAM DAN HUKUM ADAT: Anwar Hidayat, M. Gary Gagarin. A, Deny Guntara

ditunaikan laki-laki dan membeda-bedakan antara hak anak kecil perempuan mendapat hak yang sebanding dengan kewajiban yang dipikulnya masingmasing kelak dalam kehidupan keluarga dan masyarakat.

e) Asas Kewarisan Semata Akibat Kematian yaitu peralihan peninggalan seseorang kepada orang lain dengan nama kewarisan berlaku sesudah meninggalnya pewaris. Hal ini berarti bahwa peralihan kewarisan itu berlaku sesudah matinya seseorang (pewaris).

Hukum waris Islam telag menempatkan atauran kewarisan dan hukum mengenai harta benda dengan sebaik-baiknya dan seadil-adilnya. Islam menetapkan hak milik seseorang atas harta, baik bagi laki-laki maupun perempuan seperti perpindahan hak milik dan perempuan pada waktu masih hidup atau perpindahan harta kepada ahli warisnya setelah ia meninggal dunia. Ketentuan dalam Hukum Islam sendiri tidak mendiskriminasikan atau

\footnotetext{
${ }^{10}$ Dasar ketentuan sebagaimana dalam Q.S AnNisa ayat 7, Allah berfirman "Bagi laki-laki ada hak bagian harta peninggalan ibu bapak
}

\footnotetext{
dan kerabatnya, baik sedikit atau banyak menurut bahagian yang telah ditetapkan" (terjemahan).
} 
KAJIAN PERBANDINGAN DALAM PEMBAGIAN WARIS BERDASARKAN PADA HUKUM

ISLAM DAN HUKUM ADAT: Anwar Hidayat, M. Gary Gagarin. A, Deny Guntara

Ketentuan dalam hukum Islam dimana ahli waris yang berhak menerima kewarisan terdapat 25 (dua puluh lima) orang, dengan perincian lima belas orang dari pihak laki-laki dan sepuluh orang dari pihak perempuan. ${ }^{11}$ Pembagian hukum Islam sebagai berikut :

a) Ahli waris dari pihak laki-laki adalah anak laki-laki, cucu lakilaki dari anak laki-laki, bapak ,kakek, saudara laki-laki sekandung, saudara laki-laki sebapak, saudara laki-laki seibu, anak laki-laki saudara laki-laki sekandung, anak laki-laki saudara laki-laki sebapak, paman sekandung, paman sebapak, anak laki-laki paman sekandung, anak laki-laki paman sebapak, suami dan laki-laki yang telah memerdekakan hamba sahaya

b) Ahli waris dari pihak perempuan adalah anak perempuan, cucu perempuan dari anak laki-laki, ibu, nenek pihak ayah, nenek pihak ibu, saudara perempuan sekandung, saudara perempuan sebapak, saudara perempuan seibu, isteri, dan perempuan yang telah memerdekakan hamba sahaya.

Menurut hukum kewarisan Islam besar kecilnya bagian warisan setiap kerabat adalah berdasarkan derajat kekerabatan mereka. Oleh karena itu, kerabat-kerabatnya lebih kuat mendapatkan bagian yang lebih banyak. Bahkan tidak semua kerabat akan mendapatkan warisan, karena hak-hak yang dimiliki oleh sebagian kerabat akan timbul jika terdapat kerabat tertentu. Hal ini telah diatur secara jelas dalam alQuran dan as-Sunnah. Dalam hukum kewarisan Islam, sebelum harta peninggalan dibagikan maka harta peninggalan tersebut dikeluarkan dulu yang telah digunakan untuk biaya perawatan/penguburan, melunasi hutang piutang pewaris, dan melaksanakan wasiat yang dibuat oleh pewaris.

\section{b. Hukum}

Kewarisan

\section{Berdasarkan Hukum Adat}

Hukum adat merupakan suatu konsep yang sebenarnya baru dikonstruksi pada awal abad ke-20 bersama waktu dengan diambilnya

11 Asrory zain Muhammad adn Mizan, AlFaraidh (Pembagian Pusaka dalam Islam), Bina Ilmu, Surabaya, 1981, hal 9. 
KAJIAN PERBANDINGAN DALAM PEMBAGIAN WARIS BERDASARKAN PADA HUKUM

ISLAM DAN HUKUM ADAT: Anwar Hidayat, M. Gary Gagarin. A, Deny Guntara

kebijakan etis dalam tata hukum pemerintah Hindia Belanda (Indonesia) pada saat itu. Menurut Soepomo bahwa hukum adat adalah hukum non-statutoir yang sebagian besar adalah hukum kebiasaan dan sebagian kecil adalah hukum Islam, beruat akar pada kebudayaan tradisional. Sebagai ukum yang hidup, ia menjelmakan perasaan hukum yang nyata dari masyarakat. Ia senantiasa tumbuh dan berkembang seperti hidup itu sendiri. ${ }^{12}$ Hukum adat di masyarakat tampak dalam wujudnya sebagai :

a) Hukum tidak tertulis (ius non skriptum), bagian merupakan bagian yang terbesar;

b) Hukum tertulis (ius skriptum), hanya sebagian kecil saja;

c) Uraian-uraian secara tertulis.

Keberadaan hukum waris adalah salah satu bagian dari sistem kekelargaan yang ada di Indonesia. Oleh karena itu, hukum warismadat berpangkal dari bentuk masyarakat dan sifat kekeluargaan yang terdapat di Indonesia menurut sistem keturunan, dan setiap sistem keturunan yang ada mempunyai

12 I. Gede Ab. Wiranata, Hukum Adat di Indonesia, PT Citra Aditya Bakti, Bandung, 2005, hal 15

13 Zainudin Ali, Pelaksanaan Hukum Waris di Indonesia, Sinar Grafika, Jakarta, 2008, hal 26 
turun temurun dari beberapa generasi) maupun harta pusaka rendah (harta yang turun dari satu generasi). Istri mempunya rentang kendali dalam urusan rumah tangga, keluarga dan kerabatnya. Apabila istri sebagai anak tertua, maka ia bertugas menunggu harta peninggalan orang tuanya yang tidak terbagi. Dalam hal ini, suami hanya ikut serta mengurus dan menikmati saja harta tersebut tanpa hak penguasaan dan pemilikan.

b. Sistem Patrilineal, merupakan sistem keluargaan berdasarkan pertalian keturunan melaluia kebapakan yang manarik garis keturunannya dari pihak lakilaki terus ke atas. ${ }^{14}$ Sebagai anak laki-laki yang menjadi ahli waris karena anak perempuan menjadi diluar dari golongan patrilinealnya semula, sesudah mereka itu kawin. Sistem kekeluargaan patrilineal berlaku adat perkawinan dengan pembayaran jujur, dimana sesudah terjadi perkawinan antara seorang pria dan wanita, maka istri melapaskan kewargaan adat dari kerabat ayahnya dan masuk kerwargaan adat suaminya. Oleh karena itu, kedudukan suami lebih tinggi dari hak dan kedudukan istrinya.

c. Sistem Parental/Bilateral, merupakan sistem keturunan yang manarik garis keturuna kedua belah pihak bagi dari garis bapaka maupundari garis ibu. Sistem kekeluargaan parental/bilateral ini mempunyai sistem perkawinan yang tidak mengenal oembayaran jujur dan perkawinan semendo. Bila terjadi perkawinan antara seorang pria dan wanita, mereka bebas memilih untuk menetap ditempat suami atau istri atau memilih untuk membangun kehidupan batu yang lepas dari pengarus orangtua masing-masing.

${ }^{14}$ Ibid, Ali, hal 25 
Kedudukan dalam keluarga bahwa suami adalah sebagai kepala keluarga sedangkan istri sebagai ibu rumah tangga, dan harta yang diperoleh selama dalam ikatan perkawinan disebut sebagai harta perkawinan, serta harta bawaan masing-masing pihak sepanjang tidak dikuasai oleh masing-masing atau keduanya (suami-istri) berhak untuk melakukan perbuatan hukum, bagik bersama-sama maupun sendiri-sendiri, baik diluar maupun dalam pengadilan bukanlah berarti bahwa suami dan istri bebas sama sekali dari tanggungjawab untuk mengurus anggota keluarga dan orang tua kedua belah pihak sepanjang hal itu mampu dilakukannya. ${ }^{15}$

Prinsip ketentuan dalam hukum waris adat memiliki asas yang berpangkal dari sila-sila Pancasila sebagai padangan hidup bangsa Indonesia (way if of life). Mengenai

\footnotetext{
${ }^{15} \mathrm{Ibid}$, Ali, hal 27

${ }^{16}$ Aep Saifullah, Analisa Perbandingan Hukum Kewarisan Adat Sunda Dengan Hukum
}

pembagian warisan menurut adat, misalnya adalah masyarakat adat Sunda pada umumnya terbagi menjadi 2 macam cara yang dibagi kepada generasi muda, yaitu $:^{16}$

a) Pembagian sebelum generasi tua meninggal, yakni yang dimaksud generasi tua ialah bapak dan ibu dari generasi muda tersebut. Pembagian sebelum generasi tua meninggal dilakukan atas persetujuan antara suami dan isteri. Pihal generasi muda (anak-anaknya) hanya menerima saja pembagian yang dikehendaki oleh ayah bunda mereka. Harta kekayaan warisan dibagikan sama rata kepada anak-anaknya, pembagian ini tidak melihat jenis kelamin misalanya anak laki-laki mendapat satu sedangkan perempuan setengahnya. Bila pembagian tersebut sudah ditentukan jumlah besar dan banyaknya harta warisan, maka kemudian

Kewarisan Islam, Skripsi UIN Syarif Hidayatullah Jakarta, 2007, hal 52-53 
dibuatkan dan diuruskan suratsuratnya yang sah pada pamong desa.

b) Pembagian sesudah generasi tua meninggal, yakni pembagian dilakukan apabila kedua orang tua ibu dan bapak dari waris setelah meninggal. Kalau ibu saja yang meninggal, pembagian belum bisa dilakukan, bila bapak yang meninggal sednagkan ibu masih hidup, maka hak kekuatasaan atas semua jatuh kepada ibu (istri) dan ini yang mengatur segala sesuatunya mengenai harta kekayaan suaminya yang meninggal tersebut. Pemahaman lainnya ialah dengan melihat silsilah keturunan keluarga (turun teki) yakni apakah termasuk anak sulung, bungu atau bontot. Anak sulung (anak pertama) mendapatkan bagian warisan lebih besar dari adik-adiknya, selanjutnya anak kedua mendapatkan lebih kecil dari anak sulung begitupun seterusnya. Pembagian seperti ini tidak melihat jenis apakah anak laki-laki ataupun perempuan. Namun lebih kepada aspek strata keluarga.

Pembagian warisan dilaksanakan secara damai dan musyawarah yang menghasilkan mufakat antara ahli waris, setelah segala tanggungan dari orang yang meninggal, selesai ditunaikan seperti melunasi hutang-hutangnya, biaya penguburan, melaksanakan wasiatnya dan lain-lain. Kalau dengan cara ini masih belum juga selesai, maka dimintakan pertimbangan dan penyelesaian dari pihak Kantor Urusan Agama (KUA) setempat. Oleh karena itu, segala pertimbangan dan penyelesaian dilakukan berdasarkan hukum Islam sesuai ketentuan kitab faraidh.

\section{Kajian Filosofis Mengenai} Hukum Waris Berlandaskan Pada Nilai-nilai Pancasila Bangsa Indonesia

Kajian filosofis atau filsafat merupakan pemikiran yang sekan-akan berada pada ranah yang abstrak, dimana filsafat hukum sendiri mempunyai fungsi yang strategis dalam pembentukan hukum di Indonesia. Pengertian filsafat adalah pengetahuan 
KAJIAN PERBANDINGAN DALAM PEMBAGIAN WARIS BERDASARKAN PADA HUKUM

ISLAM DAN HUKUM ADAT: Anwar Hidayat, M. Gary Gagarin. A, Deny Guntara

dan penyelidikan dengan akal budi mengenai hakikat segala yang ada, sebab, asal dan hukumnya yakni suatu teori yang mendasari alam pikiran atau suatu kegiatan atau juga berarti ilmu berintikan logika, estetika, metafisika dan epistemologi.

Dalam konteksnya kajian kritis terhadap hukum perdata yang telah berlaku di Indonesia dengan menggunakan metode filsafat (filosofis), maka seharusya yang dijadikan dasar pemikirannya ialah falsafah Pancasila. Sebagaimana diketahui bahwa Pancasila merupakan sumber dari segala sumber hukum negara Indonesia. Hal yang demikian ini dirasa sesuai mengingat falsafah Pancasila adalah merupakan ruh perjuangan dari para pejuang bangsa, sebagai alat pemersatu, dari yang sebelumnya terkotak-kotak oleh suatu daerah/wilayah, ras, suku, golongan dan agama. Merupakan latar belakang dari masyarakat Indonesia yang heterogen dan majemuk, sehingga dengan didasarkan pada nilai-nilai Pancasila mampu menjunjung cita-cita luhur para pejuang untuk menciptakan masyarakat yang adil dan makmur sejahtera dapat diwujudkan bagi masyarakat Indonesia secara keseluruhan.
Sebagaimana dikemukakan diatas, Sepanjang hukum tersebut tidak bertentangan dengan Pancasila dan UUD 1945, peraturan perundang-undangan serta dibutuhkan dan apabila hukum tersebut bertentangan, maka menjadi tidak berlaku lagi. Disebut tidak berlaku bilamana terdapat Undang Undang yang bertentangan dapat diamandemenn oleh Anggota DPR dan dapat diajukan ke Mahkamah Konstitusi disebabkan Menurut Undang-Undang Dasar 1945, kewajiban dan wewenang MK adalah : berwenang mengadili pada tingkat pertama dan terakhir yang putusannya bersifat final untuk menguji UndangUndang terhadap Undang-Undang Dasar. Dalam legal awareness (kesadaran hukum), gatra kognitif merujuk pada pengetahuan seseorang tentang ada tidak aturan yang mengatur perbuatan yang sedang ia lakukan atau tengah menjadi perhatian utama, sedangkan gatra efektifnya merujuk ke pelibatan dirinya secara emosional ke suatu pihak tertentu, berdasarkan keyakinan bahwa apa yang ia ketahui itu merupakan sesuatu yang benar sehinga sudah seharusnya kalau ia turuti dan patuhi (atau merupakan ssuatu yang 
KAJIAN PERBANDINGAN DALAM PEMBAGIAN WARIS BERDASARKAN PADA HUKUM

ISLAM DAN HUKUM ADAT: Anwar Hidayat, M. Gary Gagarin. A, Deny Guntara

tidak benar, jadi sudah seharusnya dilawan). ${ }^{17}$

Dalam berfikir filsafat secara umum akan mengenalisis dengan menggunakan aspek landasan yang digunakan antara lain ontologis, epistemologis dan aksiologis. Berkaitan dengan kajian hukum perdata khsususnya mengeai hukum kewarisan yang telah berlaku di Negara Indonesia sejauh ini perlu dipahami mengenai pembagian waris itu sendiri. Bahwa berdasarkan pada aspek ontologis yang berarti ilmu yang membahas tentang hakikat sesuatu yang ada, yang merupakan ultimate reality baik yang berbentuk jasmani/konkret maupun rohani/abstrak. ${ }^{18}$ Sedangkan Suriasumantri, bahwa ontologi adalah membahas tentang apa yang ingin kita ketahui, seberapa jauh kita ingin tahu, atau suatu pengkajian mengenai teori tentang "ada". Dalam hal hukum perdata secara ontologis merupakan norma/aturan yang berisi mengenai hubungan hak dan kewajiban pada setiap diri manusia seperti perkawinan, harta benda, waris, dan lain sebagainya. Hukum perdata merupakan pedoman

17 Hadi Sutoyo, Komitmen Hukum dan Kritik Legalisme bagi Hakim, Varia Peradilan No 293, April 2010. bagi subyek hukum sebagai pelaksana dari hak dan kewajiban sebagaimana ada pada diri manusia.

Hukum kewarisan merupakan ketentuan yang mengatur mengenai perpindahan harta benda (kekayaan) seseorang kepada orang lain, dengan alasan adanya pewaris meninggal dunia. Oleh karenanya, segala harta benda yang dimiliki akan menjadi hak bagi ahli warisnya. Salah satu nilai dalam Pancasila yang berkaitan dengan hal ini, bahwa segala sesuatu diberikan secara adil dan beradab. Hukum kewarisan menjadi suatu keharusan untuk berpindah ketika waktu yang sudah ada dengan pertimbangan dari para ahli waris tersebut.

Epistimologi atau teori pengetahuan ialah cabang filsafat yang berurusan dengan hakekat dan lingkungan pengetahuan, pengandaian-pengandaian dan dasar-dasarnya serta pertanggungjawaban atas pernyataan mengenai pengetahuan yang dimiliki. Epistemologi adalah pembahasan mengenai metode yang digunakan untuk mendapatkan pengetahuan. Dalam

\footnotetext{
18 Amsal Bakhtiar, Filsafat Ilmu, Penerbit Raja Grafindo Persada, 2010, hal 35.
} 
KAJIAN PERBANDINGAN DALAM PEMBAGIAN WARIS BERDASARKAN PADA HUKUM

ISLAM DAN HUKUM ADAT: Anwar Hidayat, M. Gary Gagarin. A, Deny Guntara

konteks hukum perdata merupakan peraturan yang mengatur hal - hal yang sangat esensial bagi kebebasan individu, hak milik dan perikatan. Epistemologi dalam hukum perdata berkaitan dengan adanya peristiwa-peristiwa hukum yang dialami oleh setiap individu yang diakomodir menjadi sebuah peraturan perundang-undangan agar mampu menyelesaiakn persoalan yang terjadi pada antara indvidu tersebut.

Dalam aspek epistemologis mengenai hukum kewarisan, bahwa pembagian harta benda (kekayaan) yang menjadi obyek untuk diwariskan kepada para ahli waris pada dasarnya berasaskan keadilan dan berimbang. Dimana maksudnya ialah bagian bagi laki-laki maupun perempuan sama-sama berhak sebagai seorang ahli waris, mewarisi harta peninggalan yang ditinggalkan oleh pewaris. Oleh karena itu, harus senantiasa terdapat keseimbangan antara hak dan kewajiban, antara hak yang diperoleh seseorang dengan kewajiban yang harus ditunaikan laki-laki dan perempuan mendapat hak yang sebanding dengan kewajiban yang dibebankan masing-masing kelak dalam kehidupan keluarga dan masyarakat.

Pengertian aksiologi menurut Jujun S. Suriasumantri adalah teori nilai yang berkaitan dengan kegunaan dari ilmu pengetahuan yang diperoleh. ${ }^{19}$ Sedangkan Wibisono mengemukakan bahwa aksiologi adalah nilai-nilai sebagai tolak ukur kebenaran etika dan moral sebagai dasar normative penelitian dan penggalian serta penerapan ilmu.

Dalam aspek aksiologis mengenai hukum kewarisan, bahwa pembagian harta warisan selama ini tidaklah minim dari terjadinya perdebatan atau perselisihan yang terjadi pada para ahli waris tersebut. Banyak masyarakat yang belum memahami tentang hukum waris (baik secara Perdata Barat/BW; waris Islam; dan waris Adat) sehingga masih sering terjadi salah persepsi. Akibatnya tidak sedikit terjadi konflik atau perselisihan antara sesama ahli waris tersebut karena merasa pembagian tidak merata. Namun dalam aspek aksilogis ini merupakan aspek yang memberikan tujuan bahwa harta kewarisan yang menjadi hak bagi para ahli waris harus benar-benar mampu dibagikan sesuai

${ }^{19}$ Jujun S. Suriasumantri, Op.Cit, hal 60 
pada bagiannya, misalnya bagian lakilaki maupun perempuan dan baik anak kecil maupun orang yang telah dewasa. Semuanya merupakan ahli waris yang menurut katentuan adalah sah (berdasarkan hukum positif), maka harta warisan tersebut menjadi hak bagi mereka.

\section{KESIMPULAN}

1. Pewarisan merupakan peralihan hak pemilikan harta peninggalan (tirkah) pewaris, sehingga pewarisan sangat erat kaitannya dengan ruang lingkup kehidupan manusia, sebab setiap manusia pasti mengalami peristiwa hukum yakni kematian. Dalam hukum Islam pembagian harta peninggalan dengan membedakan bagian ahli waris atara laki-laki dan perempuan dengan ketentuan 2:1. Sedangkan dalam pembagian waris menurut hukum Adat tidaklah membedakan ahli warisan berdasarkan pada jenis kelamin, akan tetapi pembagian didasarkan pada strata keluarga seperti anak pertama akan mendapatkan harta warisan lebih besar jika dibandingkan dengan anak kedua, ketiga dan seterusnya.

2. Kajian kritis terhadap hukum perdata yang telah berlaku di Indonesia dengan menggunakan metode filsafat (filosofis), maka seharusya yang dijadikan dasar pemikirannya ialah falsafah Pancasila. Sebagaimana diketahui bahwa Pancasila merupakan sumber dari segala sumber hukum negara Indonesia. Hal yang demikian ini dirasa sesuai mengingat falsafah Pancasila adalah merupakan ruh perjuangan dari para pejuang bangsa, sebagai alat pemersatu, dari yang sebelumnya terkotak-kotak oleh suatu daerah/wilayah, ras, suku, golongan dan agama. Dalam pemikiran melalui filsafat harus dikaji berdasarkan pada aspekaspek untuk dikaji, seperti aspek ontologis, epistemologis, dan aksilogis. 


\section{DAFTAR PUSTAKA}

Ali, Muhammad Daud, 2000, Asas-asas Hukum Islam, Jakarta : Rajawali Pers

Ash-Shabuni, Muhammad Ali, 1995, Pembagian Waris Menurut Islam, (penerjemah : A.M Basamalah), Gema Insani Press

Bakhtiar, Amsal, 2010, Filsafat Ilmu, Penerbit Raja Grafindo Persada

Djakfar, Idris dan Taufik Yahya, 1995, Kompilasi Hukum Kewarisan Islam, Jakarta : PT Dunia Pustaka Jaya

Jaelani, Agil, Andri Milka, dan Muhammad Iqbal Kraus, 2016, Perbandingan Antara Hukum Waris Perdata Barat dengan Hukum Waris Islam, Artikel Hukum

Kansil, C.S.T, 2006, Pengantar Ilmu Hukum dan Tata Hukum Indonesia: Pengantar Hukum Indonesia (Jilid 2), Jakarta : BalaiPustaka

Prodjodikoro, Wirjono, 1983, Hukum Warisan di Indonesia, Bandung : Sumur Bandung
Rajai, Ali, Pembaharuan Hukum Kewarisan Islam di Indonesia (Stdui Komparatif Pemikiran Hazairin dan Munawir Sjadzali), UIN Sunan Kalijaga Yogyakarta

Saifullah, Aep, 2007, Analisa Perbandingan Hukum Kewarisan Adat Sunda Dengan Hukum Kewarisan Islam, Skripsi UIN Syarif Hidayatullah Jakarta

Satrio, J., 1992, Hukum Waris, Bandung: Alumni

Sjarif, Ahlan, Surini dan Nurul Elmiyah, 2005, Hukum Kewarisan BW "Pewarisan Menurut UndangUndang", Depok : Badan Penerbit Fakultas Hukum Universitas Indonesia Suriasumantri,Jujun S. 2001, FilsafatImu :SebuahPengantarPopuler, Jakarta : PustakaSinarHarapan
Sutoyo, Hadi, Komitmen Hukum dan Kritik Legalisme bagi Hakim, Varia Peradilan No 293, April 2010

Triwulan, Tutik Titik, Hukum Perdata dalam Sistem Hukum Nasional, Jakarta : Kencana

Zuhdi, Masjfuk, 1993, Study Islam, Jilid III, Jakarta: Raja Grafindo 